\title{
EFFECT OF LONG- AND SHORT-TERM INTRAVAGINAL PROGESTAGEN TREATMENTS ON SYNCHRONIZATION OF OESTRUS AND FERTILITY IN HEIFERS
}

\author{
J. M. SREENAN \\ The Agricultural Institute, Belclare, \\ Tuam, Co. Galway, Ireland
}

(Received 28th February 1975)

\begin{abstract}
Summary. A total of 273 Hereford cross heifers were treated with intravaginal progestagen pessaries to determine some of the factors affecting oestrous response and fertility following long-term (20-day) and short-term (10-day) treatments. Oestrous response and degree of synchronization were high after treatment for 20 days, but the fertility rate was lower than that of control heifers. There was no difference in the fertility of heifers inseminated artificially and those mated naturally. When the treatment period was reduced to 10 days and $900 \mathrm{mg}$ progesterone and $5 \mathrm{mg}$ oestradiol valerate given intramuscularly at the start, a high oestrous response and a low degree of synchronization resulted, but the conception rate was similar to that of the control animals. Reducing the dose of progesterone to $250 \mathrm{mg}$ resulted in a high oestrous response and a high degree of synchronization. The stage of the cycle at the start of the 10-day treatment did not affect the oestrous response. Retention of the progesterone pessary was low $(79.9 \%$ ) in heifers treated for 20 days, but was $100 \%$ in those treated for 10 days.
\end{abstract}

\section{INTRODUCTION}

Numerous reports dealing with the use of exogenous progestagens for control of the oestrous cycle in cattle have shown that, while oestrus and ovulation can be effectively controlled after long-term treatments (17 to 21 days), fertility at the induced oestrus is generally depressed (Hansel, 1967; Jochle, 1972). Recent reports have indicated that if the progestagen treatment is shortened to about 10 days and combined with oestrogen to cause early regression of the CL, fertility is normal at the induced oestrus (Wiltbank \& Kasson, 1968; Wiltbank et al., 1971). It has been shown that oestrogen administered early in the oestrous cycle (Days 0 to 4) will not cause CL regression in the ewe (Ginther, 1970; Hawk \& Bolt, 1970), or in the cow (Smith \& Vincent, 1973). There is evidence, however, suggesting that progesterone administration early in the cycle will facilitate oestradiol-induced regression of the CL in the ewe (Warren 
et al., 1973). Wishart \& Young (1974) administered intramuscular progestagen (SC-21009) at the start of the 9-day progestagen (SC-21009) implant treatment, to inhibit development of CL in heifers that had recently ovulated and used oestrogen as a luteolytic agent.

The aim of the present work was to determine the effectiveness of long- and short-term intravaginal progestagen treatments for control of the oestrous cycle in cattle and to study some of the factors that may affect the oestrous response and fertility at the induced oestrus.

\section{Intravaginal pessaries}

\section{MATERIALS AND METHODS}

Polyurethane sponge pessaries $(10 \times 7 \mathrm{~cm}$ cylinders; density, $0.018 \mathrm{~g} / \mathrm{ml})$ were impregnated with $3 \mathrm{~g}$ progesterone or $0.150 \mathrm{~g}$ SC-9880 (Cronolone: G. D. Searle \& Co.), and dusted with an antibiotic preparation whose active constituent is oxytetracycline (Terramycin: Pfizer Ltd) before insertion (Sreenan, 1974).

\section{Animals}

Hereford cross heifers were used, and at least one normal cycle was established in each animal before treatment. The day of the cycle at the start of treatment was recorded and groups of about ten heifers were treated to avoid large numbers for insemination at any one time. Oestrus was detected by the use of vasectomized bulls fitted with chin-ball mating harnesses. From the time of pessary removal, animals were checked for oestrus at $08.00,12.00,16.00$ and 19.00 hours for 7 days. Between 19.00 and 08.00 hours, vasectomized bulls with mating harnesses were run with the heifers. Control heifers were checked for oestrus in a manner similar to that for the treated heifers.

At the oestrus following treatment, heifers were either served by bulls of proven fertility or were artificially inseminated with frozen-thawed semen from one bull (about $30 \times 10^{6}$ spermatozoa/straw) by one inseminator. One or two inseminations were carried out about $6 \mathrm{hr}$ after the start of oestrus. All heifers were checked for the occurrence of a repeat oestrus at which they were served in a similar manner. The animals were slaughtered between 40 and 62 days from the last insemination and pregnancy rate was based on recovery of viable embryos.

Trial 1 . The 101 heifers in this trial were randomly allotted to treatments as follows. Pessaries impregnated with progesterone or SC-9880 were inserted into 46 and 33 heifers, respectively, and left in position for 20 days. Twenty-two untreated heifers, maintained under similar conditions, acted as controls. All heifers in standing oestrus after treatment and all control heifers were naturally inseminated.

Trial 2. In order to determine whether the method of breeding (natural service or A.I.) might affect conception rate at the induced oestrus, 90 cyclic Hereford cross heifers were treated as follows. Progesterone pessaries were inserted into all the heifers for 20 days. At the time of insertion, the heifers were allocated to a group of 60 and one of 30 . The heifers in the first group that showed standing oestrus after removal of the pessary were naturally mated; those in Group 2 were artificially inseminated. 
Trial 3. The 82 heifers were treated as follows. Progesterone pessaries were inserted into 25 heifers for a 10-day period and those showing oestrus after treatment were artificially inseminated. At the time of insertion, each heifer was injected with $900 \mathrm{mg}$ progesterone $+5 \mathrm{mg}$ oestradiol valerate in $30 \mathrm{ml}$ corn oil. A group of 32 heifers was similarly treated with progesterone pessaries for a 10-day period, but received $250 \mathrm{mg}$ progesterone $+7.5 \mathrm{mg}$ oestradiol benzoate in $10 \mathrm{ml}$ corn oil. These heifers were not inseminated and were used to measure repeat cycle lengths. A group of 25 heifers kept under similar conditions acted as controls.

\section{RESULTS}

Trial 1 . Only $36 / 46(78.3 \%)$ progesterone pessaries and $28 / 33(84.8 \%)$ SG9880 pessaries were retained for the full 20 -day period, and the results presented (Table 1) are only for those animals retaining pessaries for the full period.

Table 1. Oestrous response, degree of synchronization and fertility in heifers following removal of pessaries impregnated with progesterone or SC-9880 and after insertion for 20 days

\begin{tabular}{|c|c|c|c|c|c|c|c|c|}
\hline \multirow{2}{*}{ Treatment } & \multirow{2}{*}{$\begin{array}{c}\text { No. } \\
\text { off } \\
\text { heifers }\end{array}$} & \multirow{2}{*}{$\begin{array}{c}\text { No. } \\
\text { in } \\
\text { oestrus }\end{array}$} & \multicolumn{4}{|c|}{$\begin{array}{l}\text { No. of heifers in } \\
\text { oestrus on: }\end{array}$} & \multicolumn{2}{|c|}{$\begin{array}{l}\text { No. of heifers } \\
\text { pregnant after: }\end{array}$} \\
\hline & & & Day 2 & Day 3 & Day 4 & Day 5 & $\begin{array}{l}\text { First } \\
\text { service }\end{array}$ & $\begin{array}{c}\text { Two } \\
\text { services }\end{array}$ \\
\hline $\begin{array}{l}\text { Progesterone } \\
\text { SC-9880 } \\
\text { Control }\end{array}$ & $\begin{array}{l}36 \\
28 \\
22\end{array}$ & $\begin{array}{l}35(97 \cdot 2) \\
25(89 \cdot 3) \\
22(100)\end{array}$ & $\begin{array}{r}12(34 \cdot 3) \\
5(20 \cdot 0)\end{array}$ & $\begin{array}{l}20(57 \cdot 1) \\
16(64 \cdot 0) \\
\end{array}$ & $\begin{array}{l}3(8 \cdot 6) \\
1(4 \cdot 0)\end{array}$ & $3(12 \cdot 0)$ & $\begin{array}{l}18(51 \cdot 4) \\
12(48 \cdot 0) \\
15(68 \cdot 2)\end{array}$ & $\begin{array}{l}29(82.9) \\
22(88 \cdot 0) \\
20(90 \cdot 9)\end{array}$ \\
\hline
\end{tabular}

Figures in parentheses are percentages.

The progesterone treatment resulted in a higher degree of synchronization since $91.4 \%$ of heifers showed oestrus within a $48-\mathrm{hr}$ period compared with $84.0 \%$ for the SC-9880 treatment. The one progesterone-treated heifer and two of the three SG-9880 treated heifers that did not come into oestrus following treatment all exhibited oestrus between 19 and 21 days after pessary removal, indicating that ovulation did take place following treatment. No heifer showed oestrus while the pessaries were in position. The stage of the cycle at insertion did not affect the oestrous response following pessary withdrawal. Heifers treated during Days 0 to 4,5 to 16 and 17 to 20 of the cycle had oestrous responses of $81.8,100.0$ and $86.7 \%$ respectively. Heifers treated with progesterone came into standing oestrus slightly earlier $(40.7 \pm 2.5 \mathrm{hr})$ than did those treated with SC-9880 (50.0 $\pm 4.3 \mathrm{hr})$, while mean duration of oestrus was longer $(13.5 \pm 1.8 \mathrm{hr})$ than for either the SG-9880 $(9.3 \pm 1.7 \mathrm{hr})$ or the control $(10.7 \pm 2.4$ hr) groups.

There was no difference between the pregnancy rates of heifers treated with progesterone or SC-9880, and although all the treated heifers had lower pregnancy rates than the controls (Table 1), the difference was not significant $\left(\chi^{2}=1.96 ;\right.$ d.f. $\left.=2 ; P>0.1\right)$. The pregnancy rates from the first service and the 
repeat service were similar for all groups and represented breeding periods of 27 (progesterone), 26 (SC-9880) and 45 (control) days.

Table 2. Fertility in heifers after natural or artificial insemination at the synchronized and following oestrus after withdrawal of progesterone-impregnated pessaries inserted for 20 days

\begin{tabular}{lcccc}
\hline \multirow{2}{*}{ Insemination } & $\begin{array}{c}\text { No. of } \\
\text { heifers }\end{array}$ & \multicolumn{3}{c}{ No. of heifers pregnant after: } \\
\cline { 3 - 5 } & First service & Second service & Two services \\
\hline Artificial & 23 & $13(56 \cdot 5)$ & $7(70)$ & $20(87 \cdot 0)$ \\
Natural & 47 & $23(48 \cdot 9)$ & $15(62 \cdot 5)$ & $38(80 \cdot 9)$ \\
\hline
\end{tabular}

Figures in parentheses are percentages.

Table 3. The effect of 10-day progesterone treatment by intravaginal pessaries on oestrous response of heifers

\begin{tabular}{|c|c|c|c|c|c|c|}
\hline \multirow{2}{*}{$\begin{array}{l}\text { Treatment at time of } \\
\text { pessary insertion }\end{array}$} & \multirow{2}{*}{$\begin{array}{c}\text { No. } \\
\text { of } \\
\text { heifers }\end{array}$} & \multirow{2}{*}{$\begin{array}{c}\text { No. } \\
\text { in } \\
\text { oestrus }\end{array}$} & \multicolumn{4}{|c|}{ No. of heifers in oestrus on: } \\
\hline & & & Day 2 & Day 3 & $D a y 4$ & Day 5 \\
\hline $\begin{array}{l}\text { Progesterone, } 900 \mathrm{mg} \\
\text { +oestradiol valerate, } 5 \mathrm{mg}\end{array}$ & 25 & 24 & $7(29 \cdot 2)$ & $9(37 \cdot 5)$ & $2(8 \cdot 3)$ & $6(25 \cdot 0)$ \\
\hline $\begin{array}{l}\text { Progesterone, } 250 \mathrm{mg} \\
\text { +oestradiol benzoate, } 7.5 \mathrm{mg}\end{array}$ & 32 & 29 & $22(75 \cdot 8)$ & $6(20.7)$ & $1(3 \cdot 4)$ & - \\
\hline
\end{tabular}

Figures in parentheses are percentages

Table 4. The effect of the stage of the cycle at the start of 10-day treatments by intravaginal progesterone-impregnated pessaries on the oestrous response of heifers

\begin{tabular}{lccc}
\hline \multirow{2}{*}{$\begin{array}{c}\text { Treatment at time } \\
\text { of pessary insertion }\end{array}$} & \multicolumn{3}{c}{ Stage of oestrous cycle at start of treatment } \\
\cline { 2 - 4 } & Days 0 to 4 & Days 5 to 16 & Days 17 to 23 \\
\hline $\begin{array}{l}\text { Progesterone, } 900 \mathrm{mg} \\
\text { +oestradiol valerate, } 5 \cdot 0 \mathrm{mg}\end{array}$ & $4 / 4$ & $18 / 19$ & $2 / 2$ \\
$\begin{array}{l}\text { Progesterone, } 250 \mathrm{mg} \\
\text { +oestradiol benzoate, } 7.5 \mathrm{mg} \\
\text { Total }\end{array}$ & $11 / 12$ & & \\
\hline
\end{tabular}

Values are given as no. of heifers in oestrus/no. treated.

Trial 2 . Only $71 / 90(78.9 \%)$ heifers in this trial retained the pessaries and only these results are presented. Standing oestrus was exhibited in 70 heifers $(98.6 \%)$ within a period of 5 days after removal of the pessary, and most heifers were in oestrus over a 48 -hr period. The pregnancy rate (Table 2) after A.I. was similar to that after natural service $\left(\chi^{2}=0.29 ;\right.$ d.f. $\left.=1 ; P>0 \cdot 1\right)$.

Trial 3. All the pessaries were retained for the 10-day treatment period in this trial and results (Table 3 ) are presented for all animals treated. The oestrous response following both treatments was high, but that after the lower dose of 
progesterone and $7.5 \mathrm{mg}$ oestradiol benzoate was better synchronized than that after $900 \mathrm{mg}$ progesterone $+5.0 \mathrm{mg}$ oestradiol valerate. The stage of the cycle at the start of treatment had no effect on the oestrous response (Table 4). The mean onset of oestrus was much later after $900 \mathrm{mg}$ progesterone $(73.1 \pm 6.7 \mathrm{hr})$ than after $250 \mathrm{mg}$ progesterone $(44 \cdot 8 \pm 3 \cdot 4 \mathrm{hr})$.

Table 5. The effect of a 10-day progesterone treatment by intravaginal pessary on fertility of heifers

\begin{tabular}{|c|c|c|c|c|}
\hline \multirow{2}{*}{ Treatment } & \multirow{2}{*}{$\begin{array}{l}\text { No. } \\
\text { of } \\
\text { heifers }\end{array}$} & \multirow{2}{*}{$\begin{array}{l}\text { No. } \\
\text { in } \\
\text { oestrus }\end{array}$} & \multicolumn{2}{|c|}{ No. of heifers pregnant after: } \\
\hline & & & First service & Two services \\
\hline $\begin{array}{l}\text { Progesterone (pessary) } \\
\text { + progesterone, } 900 \mathrm{mg} \\
\text { +oestradiol valerate, } 5 \mathrm{mg}\end{array}$ & 25 & 24 & $15(62.5 \%)$ & $19(79 \cdot 2 \%)$ \\
\hline Control & 25 & 25 & $16(64 \cdot 0 \%)$ & $22(88.0 \%)$ \\
\hline
\end{tabular}

The pregnancy rate for the heifers treated with $900 \mathrm{mg}$ progesterone was similar to that for the control group (Table 5), and pregnancy rates of the first service and repeat service combined $(80 \%)$ were recorded for the treated and control groups and represented breeding periods of 29 and 48 days, respectively.

Most of the repeat cycles $(87.5 \%)$ exhibited by the 24 heifers receiving 250 mg progesterone $+7.5 \mathrm{mg}$ oestradiol benzoate occurred within a 17 to 25-day period. The stage of the cycle at the start of treatment did not affect the repeat cycle length.

\section{DISCUSSION}

The results presented indicate that intravaginal administration of progestagen over a 20-day period is an effective method of inducing and synchronizing oestrus and ovulation following pessary removal. However, conception rates of only about $50 \%$ were recorded at the synchronized oestrus. When the treatment period was reduced to 10 days, a higher level of fertility was recorded $(62.5 \%)$ at the synchronized oestrus.

One of the problems in administering progestagens to cattle is that of achieving a slow but continuous release of the progestagen over the treatment period. The development of the intravaginal sponge pessary for use in sheep (Robinson, 1965) also led to this method being adapted for use in cattle (Wishart \& Hoskin, 1968; Scanlon et al., 1972). One of the problems encountered in cattle has been that of poor pessary retention (Wishart \& Hoskin, 1968; Sreenan, 1974). The data from Trial 1 support previous work indicating that progesterone-impregnanted pessaries $(3.0 \mathrm{~g} ; 20$-day period) have a lower retention rate, because of their higher density, than SC-9880 pessaries (Sreenan, 1974). When the treatment period was reduced to 10 days, however, similar progesterone pessaries were retained in all cases. High retention rates over 10-day treatment periods have been subsequently confirmed (Sreenan \& Mulvehill, 1975). A very high oestrous response was recorded for the heifers treated 
with progesterone or SC-9880 in Trials 1 and 2. The lack of effect of the stage of cycle at the start of treatment was expected, since the treatment period (20 days) was sufficiently long to allow all CL to regress, irrespective of their age at the start of treatment. The value of $45 \mathrm{hr}$ for the mean onset of oestrus in progestagen-treated animals agrees with previous reports (Shimizu et al., 1967; Wishart \& Hoskin, 1968; Scanlon et al., 1972).

It is generally accepted that, in sheep, fertility is lower at the induced oestrus following long-term progestagen treatment (Moore et al., 1967; Robinson, 1971; Robinson et al., 1968) and similar findings after progestagen treatment in cattle have been recorded (see Jochle, 1972). In this study, fertility at the synchronized oestrus after the long-term progestagen treatments was approximately $18 \%$ lower than in control animals. There is evidence to suggest that sperm transport may be adversely affected following long-term progestagen treatments in sheep (Quinlivan \& Robinson, 1969). In cattle, Lauderdale \& Ericsson (1970) have suggested that progestagen treatments may lead to an increase in the rate of sperm phagocytosis by leucocytes in the reproductive tract. These problems could be expected to be overcome by the insemination of increased sperm numbers, but the similar results in the present experiments after natural or artificial insemination seem to preclude these causes. It is possible that long-term (20-day) treatment with exogenous progestagens leads to endogenous hormonal imbalance and results in an unsuitable environment within the reproductive tract (Britt \& Ulberg, 1972; Rodeffer et al., 1972; Henricks et al., 1973).

Wiltbank \& Kasson (1968) reported normal fertility levels after 10-day progestagen treatments. They incorporated an injection of oestrogen at the start of the treatment period to induce premature CL regression. Using a potent progestagen (SC-21009) implant for a 9-day period, Wishart \& Young (1974) incorporated a combination of intramuscular SC-21009 at the start of treatment to inhibit GL development and oestrogen to cause regression of mature CL. In the present study the incorporation of $900 \mathrm{mg}$ progesterone with oestrogen at the start of a 10-day intravaginal treatment resulted in a high oestrous response in heifers treated at all cycle stages, but the onset of oestrus was delayed $(73 \cdot 1 \pm 6 \cdot 7 \mathrm{hr})$. Reducing the level of intramuscular progesterone to $250 \mathrm{mg}$ resulted in a high oestrous response and a high degree of synchronization with $96.5 \%$ of the heifers responding and showing oestrus within $72 \mathrm{hr}$. The repeat cycle lengths of 17 to 25 days in the inseminated heifers indicate that ovulation accompanied the synchronized oestrus after treatment, and this is in agreement with the data of Wishart \& Young (1974). Following the insertion of silastic implants containing $4.0 \mathrm{~g}$ progesterone and intramuscular injection of $50.0 \mathrm{mg}$ progesterone and $5.0 \mathrm{mg}$ oestradiol, Roche (1974) reports a lower oestrous response when treatment was started in the early phase of the cycle (Day 3). However, the level of intramuscular progesterone administered in that study was lower than either of the levels studied here.

The fertility of heifers after the short-term treatment did not differ from that of controls, and this finding is in accord with the reports of Roche (1974) and Wishart \& Young (1974). Subsequent data indicate normal fertility after insemination on a fixed-time basis (Sreenan \& Mulvehill, 1975). 
ACKNOWLEDGMENTS

Thanks are due to Mr D. Wishart, G. D. Searle \& Co. Ltd, for the SG-9880 (Cronolone), Mr A. McDonagh for excellent technical assistance and Mr G. Morris and Mr P. Greaven for help at all stages of this work.

\section{REFERENCES}

BrItT, J.H. \& Ulberg, L.C. (1972) Melengestrol acetate administration to dairy heifers and progestagen levels in the peripheral blood plasma. F. Reprod. Fert. 29, 119-122.

GinTHER, O.J. (1970) Length of oestrous cycle in sheep treated with oestradiol. Am. F. vet. Res. 31, 973-975.

HANSEL, W. (1967) Control of the ovarian cycle in cattle In Reproduction in the Female Mammal, pp. 419455 Eds G. E. Lamming \& E. C. Amoroso. Butterworths, London.

HAwk, H.W. \& BolT, D.J. (1970) Luteolytic effect of oestradiol-17 $\beta$ when administered after midcycle in the ewe. Biol. Reprod. 2, 275-278.

Henricks, D.M., Hill, J.R. \& Dickex, J.F. (1973) Plasma ovarian hormone levels and fertility in beef heifers treated with melengestrol acetate (MGA). F. Anim. Sci. 37, 1169-1175.

Jochle, W. (1972) Pharmacological aspects of the control of the cycle in domestic animals. Proc. 7th Int. Congr. Anim. Reprod. \& A.I., Munich 1 97-124.

LAUDERDale, J.W. \& Ericsson, R.J. (1970) Studies in oestrus control in cattle. Biol. Reprod. 2, 159-176.

MoORE, N.W., QuinLIVAN, T.D., RoBinson, T.J. \& SMITH, J.F. (1967) The fertilization of ova following natural mating or artificial insemination after withdrawal of SC-9880 impregnated intravaginal sponges from cyclic Merino ewes. In The Control of the Ovarian Cycle in the Sheep, pp. 169-176. Ed. T. J. Robinson. Sydney University Press.

QuinLIVAN, T.D. \& Robinson, T.J. (1969) Number of spermatozoa in the genital tract after artificial insemination of progestagen-treated ewes. 7. Reprod. Fert. 19, 73-86.

RoBinson, T.J. (1965) Use of progestagen-impregnated sponges inserted intra-vaginally or subcutaneously for the control of the oestrous cycle in the sheep. Nature, Lond. 206, 39-41.

Robinson, T.J. (1971) The seasonal nature of reproductive phenomena in the sheep. II. Variation in fertility following synchronization of oestrus. F. Reprod. Fert. 24, 19-27.

Robinson, T.J., Quinlivan, T.D. \& Baxter, C. (1968) The relationship between dose of progestagen and method of preparation of intravaginal sponges on their effectiveness for the control of ovulation in the ewe. F. Reprod. Fert. 17, 471-483.

Roche, J.F. (1974) Effect of short-term progesterone treatment on oestrous response and fertility in heifers. F. Reprod. Fert. 40, 433-440.

Rodeffer, G.H., Hopwoon, M.L. \& Wiltbank, J.N. (1972) LH and estrogens following estrous control. F. Anim. Sci. 34, 901.

SCANLON, P.F., SREenAN, J. \& Gordon, I. (1972) Synchronization of oestrus in heifers by intravaginal application of progesterone. Vet. Rec. 90, 440-441.

Shimizu, H., Toyoda, Y., TAkeuchi, S., Kawai, T. \& Adachi, S. (1967) Synchronization of oestrus and subsequent fertility of beef cattle following the intravaginal administration of gestagen. $\mathcal{F}$. Reprod. Fert. 13, 555-558.

SMith, L.E. \& VincENT, C.K. (1973) Stage of cycle effect on bovine estrous control. F. Anim. Sci. 36, 216.

Sreenan, J. (1974) Retention of intravaginal sponge pessaries by cattle. Vet. Rec. 94, 45-47.

SREenAN, J.M. \& MULVEHill, P. (1975) The application of long- and short-term progestagen treatments for oestrous cycle control in heifers. F. Reprod. Fert. 45, 367-369.

WARREN, J.E., JR, HAWK, H.W. \& BoLT, D.J. (1973) Evidence for progestational priming of oestradiolinduced luteal regression in the ewe. Biol. Reprod. 8, 435-440.

WiltBank, J.N. \& Kasson, C.W. (1968) Synchronization of estrus in cattle with an oral progestational agent and an injection of an estrogen. F. Anim. Sci. 27, 113-116.

Wiltbank, J.N., Sturges, J.C., Wideman, D., Le Fever, D.G. \& Faulkner, L.C. (1971) Gontrol of estrus and ovulation using subcutaneous implants and estrogens in beef cattle. F. Anim. Sci. 33, $600-606$.

WishaRT, D.F. \& Hoskin, B.D. (1968) Synchronization of oestrus in heifers using intravaginal pessaries impregnated with SC-9880 and PMSG. F. Reprod. Fert. 17, 285-289.

Wishart, D.F. \& Young, I.M. (1974) Artificial insemination of cattle at a predetermined time following treatment with a potent progestin (SC-21009). Vet. Rec. 95. 503-508. 